\title{
Chapter 6 \\ Continuous Kaizen Implementation to Improve Leanness: A Case Study of Indian Automotive Assembly Line
}

\author{
Narpat Ram Sangwa and Kuldip Singh Sangwan (i)
}

\begin{abstract}
This study aims at introducing the concept of continuous kaizen to improve the leanness by enhancing productivity, line balancing and line efficiency of an automotive component assembly line. The present study shows the implementation of continuous kaizen at an assembly line using case study methodology. The proposed continuous kaizen implementation methodology illustrates how the top management specified goals/targets for the overall improvement of the line are achieved. The quality control techniques of Gemba walk, 3M (muda, mura, muri) analysis and ECRS (eliminate, combine, reduce, or eliminate) study are used for the micro analysis of the activities. It is found that the continuous kaizen can be effectively implemented in assembly lines to improve leanness by enhancing productivity, line balancing and line efficiency. It has been shown through the case study that the new concept of continuous kaizen decreased cycle time from 80 to $75 \mathrm{~s}$, increased productivity by $6.7 \%$, and line efficiency by $2.9 \%$. The line balancing is also improved by decreasing the cycle time variation (standard deviation) from 4 to $2.84 \sigma$.
\end{abstract}

Keywords Continuous kaizen $(\mathrm{CK}) \cdot$ Leanness $\cdot$ Assembly line

\subsection{Introduction}

The organizations are implementing continuous improvement programs based on the philosophies of lean manufacturing, six sigma, total quality management (TQM), etc. to enhance customer satisfaction (Yang et al. 2016). The continuous improvement is a culture of consistent enrichment aiming at the identification and elimination of lean waste from the processes of an organization (Bhuiyan and Baghel 2005).

\footnotetext{
N. R. Sangwa

Department of Mechanical Engineering, Manda Institute of Technology, Bikaner, India

K. S. Sangwan $(\varangle)$

Department of Mechanical Engineering, Birla Institute of Technology and Science, Pilani Campus, Pilani 333031, RJ, India

e-mail: kss@ pilani.bits-pilani.ac.in 
Continuous small and incremental kaizen activities over a period of time lead to large improvements. The kaizen is a kind of project having the potential for the improvement of worker involvement and the organizational performance at the same time (Farris et al. 2008).

Chung (2018) claimed that kaizen is not similar to "improvement" in its usual nous. Suárez-Barraza et al. (2011) identified two interpretations of kaizen: the western explanation of kaizen as "continuous improvement" and the Japanese interpretation of kaizen as improvement by involving everyone alike. In western countries, the continuous improvement is termed as the kaizen and seen as a corporate proficiency that is practised as a part of either TQM or various other innovation and improvement programs (Bessant 2003). Whereas in Japan, the kaizen is described as a philosophy of conducting improvement activities at the workplace by involving everyone alike (Imai 1986). Aoki (2008) highlights the need to comprehend not only the execution of kaizen activities but also the spirit of kaizen in more depth. Thus, present study proposes a new delineation of kaizen - 'continuous kaizen (CK)'. The paper defines 'continuous kaizen' as continuous and comprehensive improvement for the completeness at the global or whole value chain level instead of just 'change for better' at local or single workstation, so as to imply the value of integration in kaizen activities. The 'continuous kaizen' focuses on three key aspects:

- Kaizen should be throughout the value chain-the kaizen should be small, incremental, continuous, and comprehensive improvement.

- Kaizen should involve everyone from everywhere - the multi-hierarchical crossfunctional team should perform kaizen activities in a specified timeframe to achieve pre-defined goal(s).

- Kaizen should improve leanness - the kaizen should improve the leanness level of the organization by systematic identification and elimination of various lean wastes.

There is still scant research on the kaizen activities in automotive component organizations (tier one supplier) as compared to automotive organizations (MarinGarcia et al. 2009) and the implementation of the kaizen is also lesser outside the Japan (Aoki 2008). The meagre research on kaizen at the automotive assembly lines is best described by the difficulties associated with the implementation of kaizen at assembly lines. Leanness improvement of an automotive assembly line is challenging to improve as the number of processes involves a large number of components and sub-assemblies to make the final product (Salzman 2002). Assembly processes are prone to errors due to their complexity, resulting in higher costs and longer cycle times. The assembly processes are difficult to map and examine as compared to production. This case study demonstrate the implementation of continuous kaizen at an auto component assembly line to improve leanness. 


\subsection{Literature Review}

Kaizen focuses on problem identification and its root causes and provides the creative solutions (Vonk 2005). The kaizen activities are used for the value addition to products and/or services (Marin-Garcia et al. 2018). The kaizen implementation attracts many organizations since it provides several qualitative and quantitative benefits to the organizations. The qualitative benefits are often related to human resource such as improvement in worker skills and commitment (Marin-Garcia et al. 2009); self-esteem and motivation (Alukal and Manos 2006); staff participation, training, communication, teamwork, and greater job satisfaction (Alvarado-Ramírez et al. 2018; Suárez-Barraza and Ramis-Pujol 2010). The quantitative benefits are linked to the economic factors such as increased productivity, profit, and inventory turnover (Oropesa et al. 2016); reduced lead times, cost, defects, and number of stages in production processes (Ramadani and Gerguri 2011).

The numerous tools, techniques and methods for kaizen implementation exist in the literature (Marin-Garcia et al. 2018). Typically, kaizen tools and techniques are human-based and process-oriented, while kaizen itself is continuous, incremental, and hands-on in nature (Suárez-Barraza et al. 2011; Alvarado-Ramírez et al. 2018). Suárez-Barraza and Lingham (2008) also identified four dimensions of kaizenoffice kaizen, Gemba-kaizen, kaizen blitz, and kaizen teian. Marin-Garcia et al. (2018) have identified eight different types of tools and techniques for the implementation of kaizen activities — quality circles, ad hoc groups, suggestion systems in permanent teams, kaizen blitz, improvement teams, self-regulated work teams, and kaizen event.

\subsection{Research Methodology}

The research methodology for continuous kaizen is shown in Fig. 6.1.

\subsection{Case Study}

The present study illustrates a case of Indian automotive component assembly line, where management is worried about the challenges of lower productivity due to higher cycle time. 


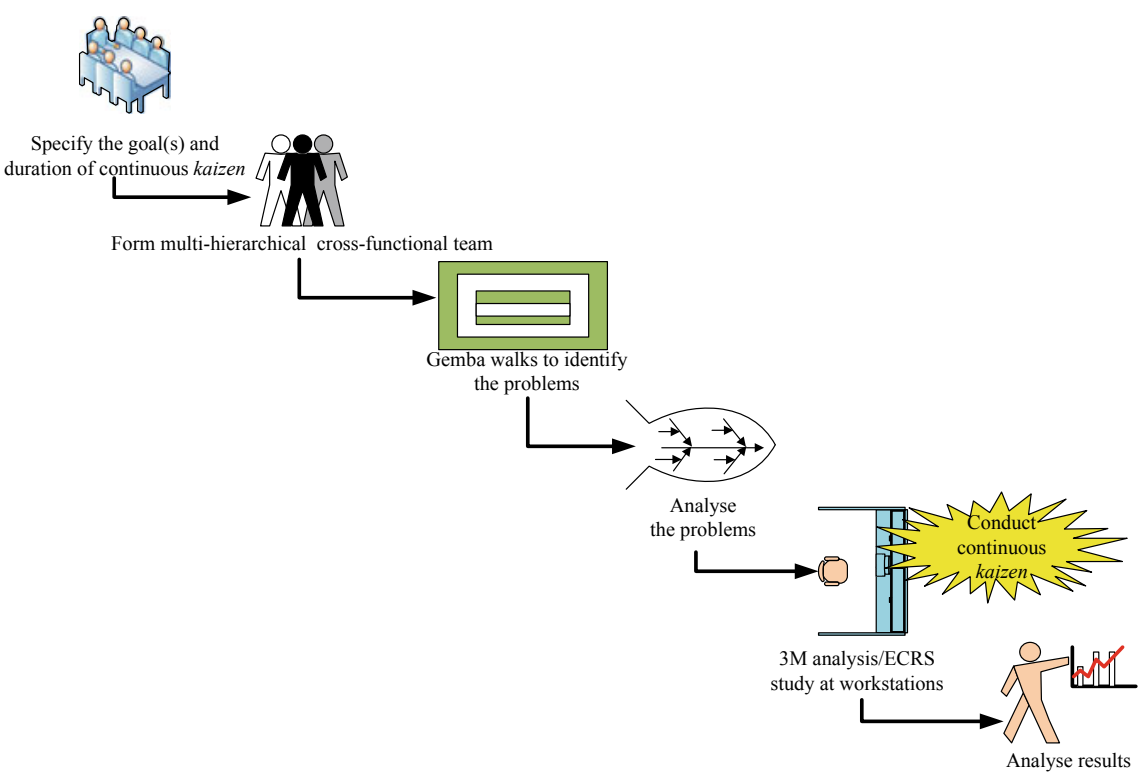

Fig. 6.1 Research methodology for continuous kaizen

\subsubsection{Case Organization}

The ABCL (organization identity is hidden for the confidentiality) is one of the prominent multinational automotive component manufacturer of India. ABCL has received the TPM excellence award in the year 2007 and Deming prize in the year 2003 and possesses ISO 9001, ISO 14001 and TS 16949 certifications. The ABCL has seven plants all over India and the case study is conducted in one of these seven plants established plant in the year 2011. The plant has various machining and assembly lines_-idler machining, rack housing, idler assembly, steering column assembly, rack and pinion sub-assembly, universal joint (UJ) assembly, and intermediate shaft assembly line. The top management agreed to implement the 'continuous kaizen' as a line improvement project. Since, the 'continuous kaizen' is a short-term project without much investment.

\subsubsection{Specify the Goals and Project Duration}

The main features of continuous kaizen project are to specify the goals or targets of improvement initiatives within a defined period. The management gave a target of $5 \%$ increase in productivity and line efficiency. The project duration was fixed as 3 months to carry out continuous kaizen activities throughout the value chain (line). 


\subsubsection{Form Multi-hierarchical Cross-Functional Team}

A multi-hierarchical cross-functional team comprising 10 internal members and two members as external experts. The team involved four head of departments at senior manager level from production, quality, manufacturing engineering (ME), and production planning and control (PPC) departments; two team leaders (TLs) at the manager level from ME and PPC departments; two assistant team leaders (ATLs) at the supervisor or assistant manager level from quality and production departments; two operators at the operational level; and the authors of the study as external experts.

\subsubsection{Gemba Walks to Identify the Problems}

To analyse the present situation of the line, the team obeyed the lean concept of "walk the flow, create the flow". A series of Gemba walks were conducted to understand the various problems associated with steering column assembly line. Figure 6.2 clearly depicts that a number of processes are arranged in parallel, which create problems to understand and analyse the process flow. The steering column assembly requires 18 processes and ten operators. Since the number of processes are more than the number of operators, therefore multi-machine activities (MMA) are considered as a work cell as shown in Fig. 6.2. Figure 6.3 clearly shows that there is large variation

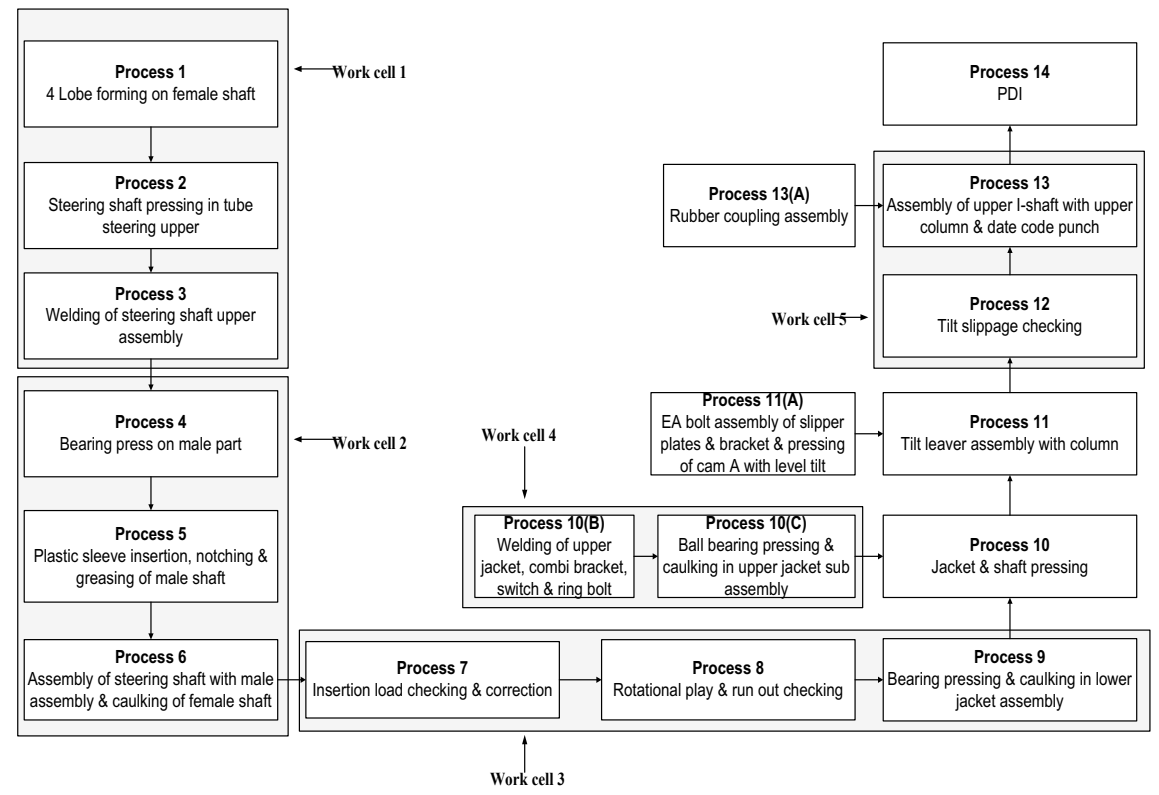

Fig. 6.2 Process sequence of steering column assembly 


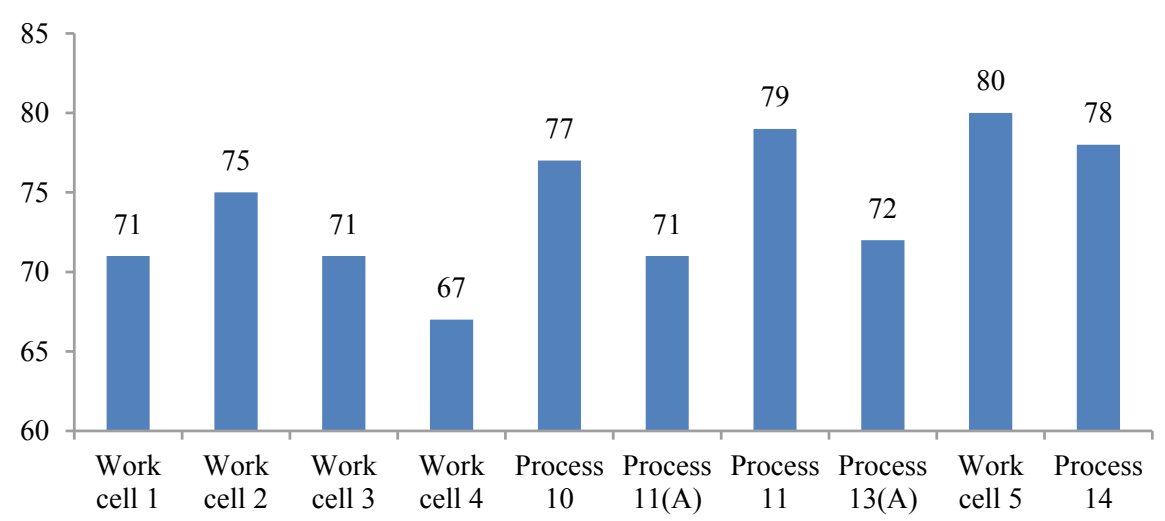

Fig. 6.3 Cycle time of the selected assembly line

in the cycle time (varies from 67 to 80 s) which unbalances the line. Similarly, the overall cycle time of the line is $80 \mathrm{~s}$. The work cell 5 is the bottleneck and has the highest cycle time of $80 \mathrm{~s}$, which results in low productivity.

\subsubsection{Analyze Various Lean Wastes}

Defect Waste. A fishbone diagram is developed to analyse the problem of defect waste and identify the root causes for the same. There are number of possible causes for the defect waste as shown in Fig. 6.4. The root cause for the large number of defects is poor load cell performance at process 7 .

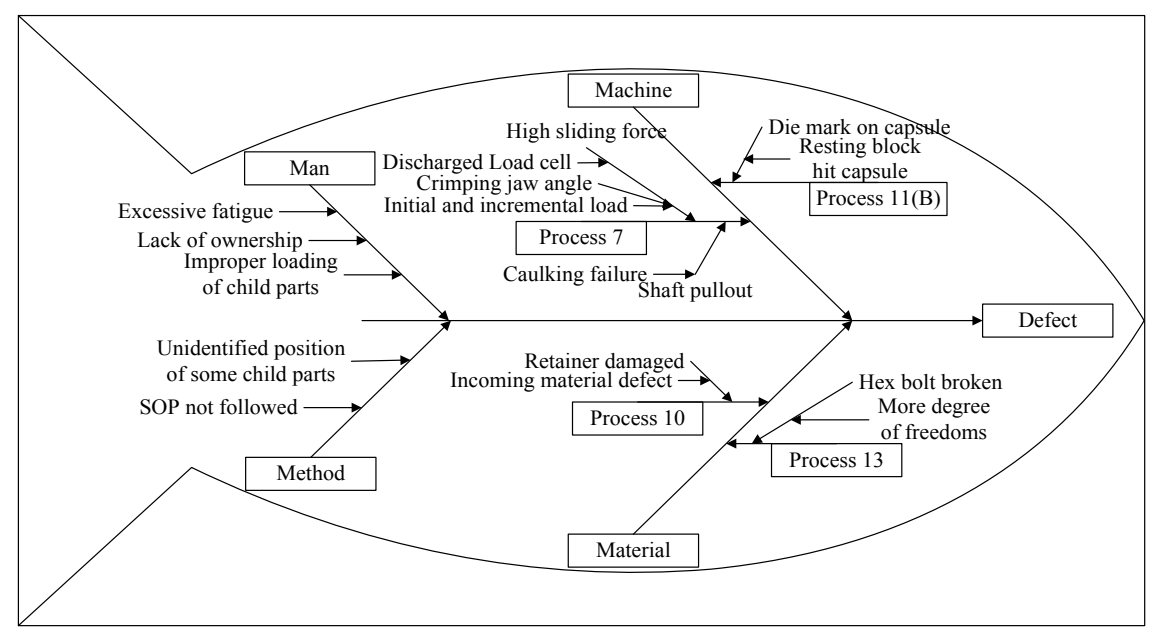

Fig. 6.4 Fishbone diagram for defect waste 
WIP Inventory. The possible causes of WIP inventory waste are sorted by man, machine, material, and method causes (Fig. 6.5). The push system used to place the child parts at the various workstations is the root cause of excessive WIP inventory of child parts.

Waiting Waste. The fishbone diagram depicts the possible causes of waiting waste (Fig. 6.6). Two major causes of the waiting waste are unavailability of bought out parts (BOP) and machine breakdown.

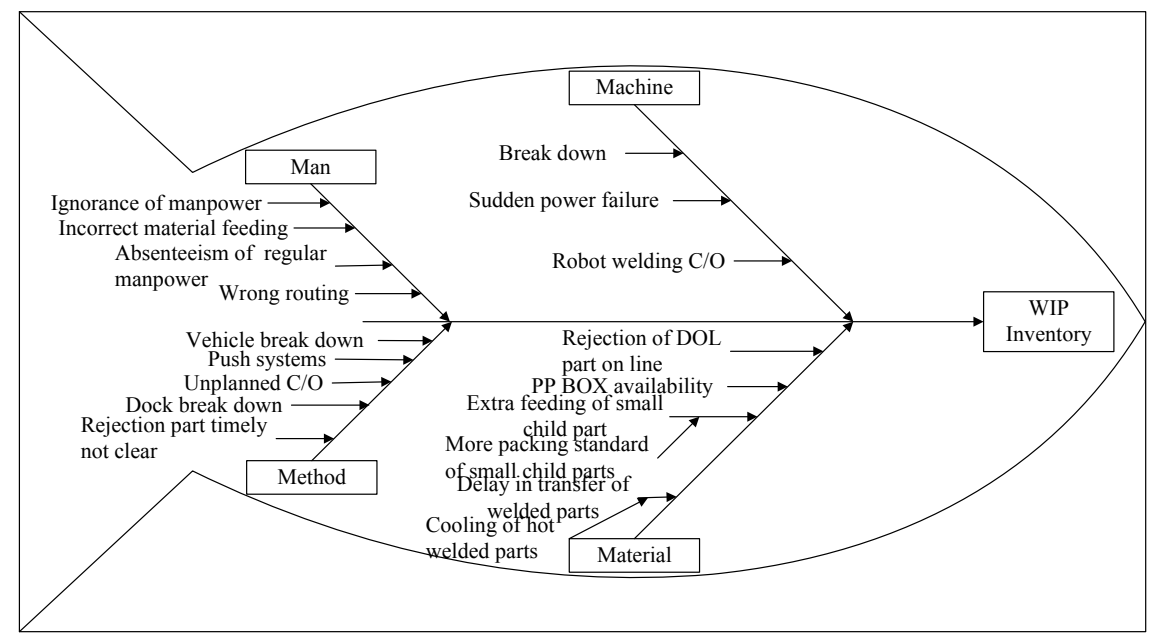

Fig. 6.5 Fishbone diagram for WIP inventory waste

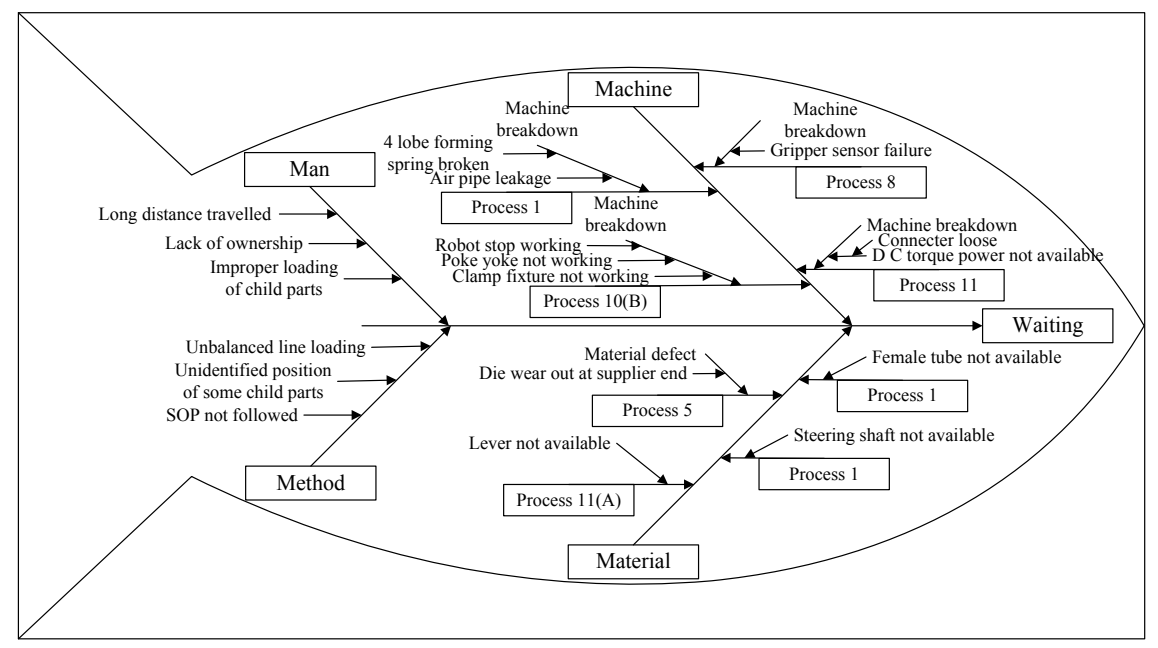

Fig. 6.6 Fishbone diagram for waiting waste 
Motion Waste. The motion waste leads to high cycle time at some processes. The possible causes of motion waste are sorted by man, machine, material, and method causes (Fig. 6.7). The team found that the poor line layout and poor workstation design are the root causes of the motion waste.

Transportation Waste. The multi-hierarchical cross-functional team conducted the brainstorming session to identify and analyse the possible causes of transportation waste. Total nine possible causes are listed as presented in Table 6.1. The team concluded that the poor line layout is the root cause of transportation waste. There are a number of zigzag movements of material and operators due to the poor layout design causing transportation waste.

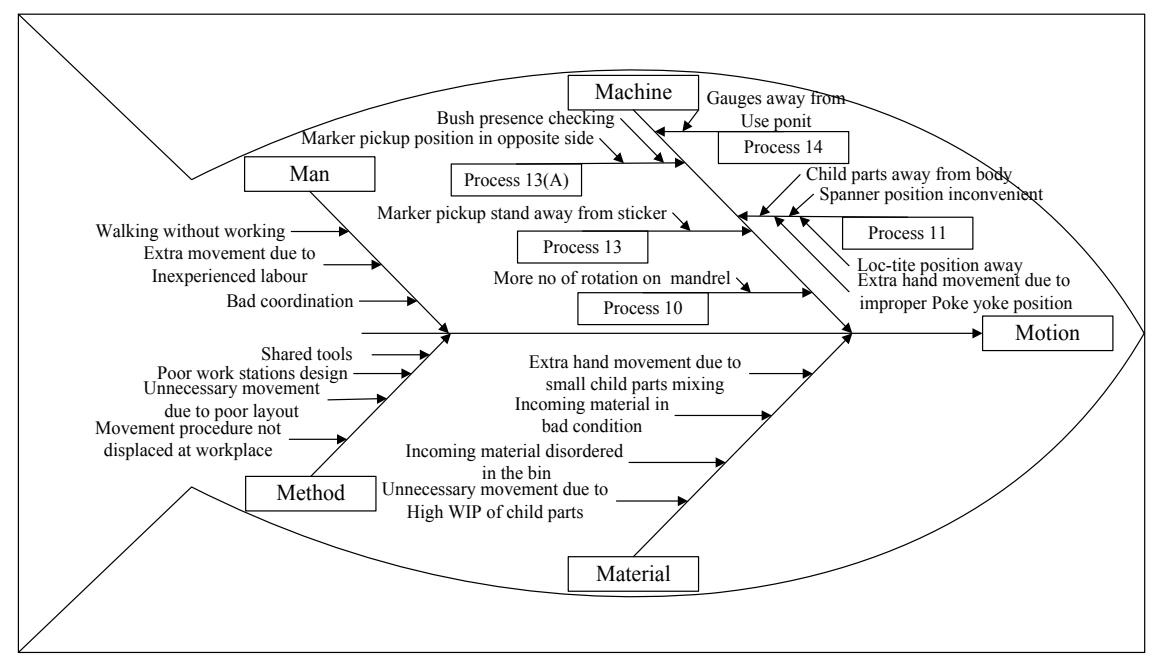

Fig. 6.7 Fishbone diagram for motion waste

Table 6.1 Possible causes of transportation waste after brainstorming session

\begin{tabular}{l|l}
\hline S. No. & Possible cause \\
\hline 1. & Wrong routing for child part feeding \\
\hline 2. & More space required due to high WIP \\
\hline 3. & Improper bin sizes \\
\hline 4. & Poor line layout \\
\hline 5. & Poor trolley design \\
\hline 6. & Poor material handling \\
\hline 7. & Single storage location \\
\hline 8. & $\begin{array}{l}\text { Complex working environment due to large no of } \\
\text { child parts }\end{array}$ \\
\hline 9. & Poor consideration to material flow \\
\hline
\end{tabular}


After analysing different types of lean wastes, the team summarised these wastes in terms of occurrence of these wastes at individual processes, their root causes, possible solutions, and the improvement plans. The team categorized the improvement plans into long-term (up to one year) and short-term (0-3 months). The motion waste due to poor workstation design can be reduced by implementing the continuous kaizen at various workstations in the given project duration of three months. Thus, the team decided to implement the continuous kaizen to reduce or eliminate the motion waste at various workstations to improve line leverage by enhanced the productivity, line balancing and line efficiency of steering column assembly line.

\subsubsection{Implementation of Continuous Kaizen}

A series of kaizen activities are carried out at the various processes to accomplish the continuous kaizen. The team first conducted the $3 \mathrm{M}$ analysis and ECRS study (process 13A) to minutely understand the different activities at the individual processes.

Kaizen at Process 14. The process 14 is pre dispatch inspection (PDI) and this is the last process of the steering column assembly line. Further, this process has high cycle time of $78 \mathrm{~s}$. Thus, process 14 is the pacemaker process and decides the heartbeat of the assembly line. The fishbone diagram of motion waste (Fig. 6.7) shows that the high cycle time is due to unnecessary movement of the operator. To critically analyse the situation, the cross-functional team did the $3 \mathrm{M}$ analysis of process 14 as presented in Table 6.2.

The team decided to implement the kaizen for the improvements of these two activities. First, the team found that the activity of 'press enter key' just after scanning the sticker code is not required and can be eliminated by changing the software of computer. The activity was eliminated by improving the software. This elimination of unnecessary hand movement decreased the activity duration from six seconds to four seconds and reduced the operator fatigue. Second, there was an unnecessary movement of operator due to poor trolley design. The cross-functional team suggested improvement in the existing trolley design. The new trolley reduced the operator movement and decreased the activity duration from nine seconds to three seconds. Thus, the cycle time of process 14 is reduced from 78 to $70 \mathrm{~s}$.

Kaizen at work cell 5. Next, the work cell 5 has two processes: process 12 and process 13 . To comprehend the whole activities of work cell 5, the cross-functional team carried out $3 \mathrm{M}$ analysis as presented in Table 6.3. After $3 \mathrm{M}$ analysis, the team found that the process 11 operator can carried out the two of the process 12 activities (load the part and start cycle). This reduced the cycle time of work cell 5 by four seconds. The process 13 is used to assemble upper I-shaft and upper steering column and to punch the date code on the part. The marker used to write on the sticker was far away from the writing area in the existing working condition. This kaizen reduced the hand movement from 240 to $80 \mathrm{~mm}$ and saved $2 \mathrm{~s}$ per part. For the work cell 5, total cycle time reduces from 80 to $74 \mathrm{~s}$. 
Table 6.2 3M analysis of process 14

\begin{tabular}{|c|c|c|c|c|}
\hline S. No. & Process 14 & Time (sec) & Observation & Action plan \\
\hline 1 & $\begin{array}{l}\text { Uplift lower jacket } \\
\text { and apply cotton }\end{array}$ & 3 & & \\
\hline 2 & $\begin{array}{l}\text { Confirmation of } \\
\text { torque on bolt }\end{array}$ & 4 & & \\
\hline 3 & $\begin{array}{l}\text { Down lower jacket } \\
\text { and check lever } \\
\text { movement }\end{array}$ & 6 & & \\
\hline 4 & $\begin{array}{l}\text { Pick-up marker, mark } \\
\text { on part }\end{array}$ & 6 & & \\
\hline 5 & $\begin{array}{l}\text { Gauge checking and } \\
\text { marking }\end{array}$ & 3 & & \\
\hline 6 & Apply cover on part & 3 & & \\
\hline 7 & $\begin{array}{l}\text { Put marker and press } \\
\text { push button to } \\
\text { unclamp }\end{array}$ & 5 & & \\
\hline 8 & $\begin{array}{l}\text { Scan sticker code and } \\
\text { press enter key on the } \\
\text { keyboard }\end{array}$ & 6 & $\begin{array}{l}\text { Unnecessary hand } \\
\text { movement for } \\
\text { pressing the enter key }\end{array}$ & $\begin{array}{l}\text { Eliminate the } \\
\text { unnecessary hand } \\
\text { movement by } \\
\text { improving the } \\
\text { software }\end{array}$ \\
\hline 9 & $\begin{array}{l}\text { Pick-up part from } \\
\text { fixture and put on } \\
\text { next fixture }\end{array}$ & 4 & & \\
\hline 10 & $\begin{array}{l}\text { Rotation torque } \\
\text { checking }\end{array}$ & 4 & & \\
\hline 11 & $\begin{array}{l}\text { Thread checking } \\
\text { using Go gauge }\end{array}$ & 3 & & \\
\hline 12 & $\begin{array}{l}\text { Thread checking } \\
\text { using No-Go gauge }\end{array}$ & 2 & & \\
\hline 13 & $\begin{array}{l}\text { Serration checking } \\
\text { using Go gauge }\end{array}$ & 3 & & \\
\hline 14 & $\begin{array}{l}\text { Serration checking } \\
\text { using No-Go gauge }\end{array}$ & 2 & & \\
\hline 15 & $\begin{array}{l}\text { Flush pin checking } \\
\text { using gauge }\end{array}$ & 4 & & \\
\hline 16 & $\begin{array}{l}\text { Apply cover on } \\
\text { thread }\end{array}$ & 3 & & \\
\hline
\end{tabular}

(continued) 
6 Continuous Kaizen Implementation to Improve Leanness ...

Table 6.2 (continued)

\begin{tabular}{l|l|l|l|l}
\hline S. No. & Process 14 & Time $(\mathrm{sec})$ & Observation & Action plan \\
\hline 17 & $\begin{array}{l}\text { Pick-up part, put on } \\
\text { trolley and trolley } \\
\text { adjustment after } \\
\text { every 6 parts }\end{array}$ & 9 & Poor trolley design & New trolley design \\
\hline 18 & $\begin{array}{l}\text { Come back for next } \\
\text { cycle }\end{array}$ & 3 & & \\
\hline 19 & $\begin{array}{l}\text { Shift loaded trolley } \\
\text { (after 24 parts) and } \\
\text { bring empty trolley } \\
\text { for next loading }\end{array}$ & 5 & & \\
\hline
\end{tabular}

Table 6.3 3M analysis of work cell 5

\begin{tabular}{|c|c|c|c|c|}
\hline S. No. & Work cell 5 & Time (sec) & Observation & Action plan \\
\hline 1 & Unload the part & 4 & & \\
\hline 2 & Load the part & (2) & $\begin{array}{l}\text { Can be accomplished } \\
\text { by previous operator }\end{array}$ & $\begin{array}{l}\text { Assign this activity to } \\
\text { process } 11 \text { operator }\end{array}$ \\
\hline 3 & Start cycle & (2) & $\begin{array}{l}\text { Can be accomplished } \\
\text { by previous operator }\end{array}$ & $\begin{array}{l}\text { Assign this activity to } \\
\text { process } 11 \text { operator }\end{array}$ \\
\hline 4 & Put part on fixture & 4 & & \\
\hline 5 & $\begin{array}{l}\text { Pick-up coupling and } \\
\text { check gauge }\end{array}$ & 6 & & \\
\hline 6 & $\begin{array}{l}\text { Insert coupling in } \\
\text { shaft and clamp }\end{array}$ & 4 & & \\
\hline 7 & $\begin{array}{l}\text { Pick-up bolt and } \\
\text { washer and fit in part }\end{array}$ & 5 & & \\
\hline 8 & Apply torque & 7 & & \\
\hline 9 & $\begin{array}{l}\text { Paste part number } \\
\text { sticker }\end{array}$ & 6 & & \\
\hline 10 & Start cycle & 2 & & \\
\hline 11 & $\begin{array}{l}\text { Write lever force on } \\
\text { sticker and paste }\end{array}$ & (10) & $\begin{array}{l}\text { Marker pick-up stand } \\
\text { is away from the } \\
\text { writing point }\end{array}$ & $\begin{array}{l}\text { Place the marker near } \\
\text { to the writing area }\end{array}$ \\
\hline 12 & $\begin{array}{l}\text { Pick-up polythene } \\
\text { and rubber and apply } \\
\text { on part }\end{array}$ & 8 & & \\
\hline 13 & $\begin{array}{l}\text { Pick-up marker and } \\
\text { do marking }\end{array}$ & 8 & & \\
\hline 14 & $\begin{array}{l}\text { Unload, and load part } \\
\text { on next bin }\end{array}$ & 6 & & \\
\hline
\end{tabular}


Table 6.3 (continued)

\begin{tabular}{l|l|l|l|l}
\hline S. No. & Work cell 5 & Time $(\mathrm{sec})$ & Observation & Action plan \\
\hline 15 & Press push button & 2 & & \\
\hline 16 & $\begin{array}{l}\text { Pick-up next part for } \\
\text { next cycle }\end{array}$ & 4 & & \\
\hline
\end{tabular}

Kaizen at process $13(\mathrm{~A})$. The process $13(\mathrm{~A})$ is rubber coupling assembly. In this process, the team decided to conduct the ECRS (eliminate, combine, reduce, or shift) study instead of $3 \mathrm{M}$ analysis. The team observed that the process 13(A) had number of activities, which can be eliminated or combined or reduced or shifted as presented in Table 6.4. Two activities (17 and 18 in Table 6.4) were identified as poor activities. After identification of poor activities, the team decided to implement the kaizen. Three kaizen activities are carried out for improvement of the process 13(A). First, the marker pickup position was on the opposite side of the picking hand and away from the sub-assembly (part). This sub-activity can be reduced by relocating the marker on right hand side and near to the sub-assembly. This relocation of marker position reduces the operator fatigue and cycle time by $0.6 \mathrm{~s}$ per part. Second, the operator code is required due to WIP inventory of sub-assemblies. This sub-activity is eliminated by implementing the single piece flow. This kaizen further reduced the activity duration by $0.4 \mathrm{~s}$ per part. Third, the activity of 'check bush presence' required $3 \mathrm{~s}$ to complete. This activity is shifted to previous workstation of universal joint (UJ) assembly line. Thus, the activity of 'check bush presence' can be carried out in UJ assembly line. The team shifted this activity to previous workstation resulting in the reduction of cycle time of process 13(A) by three seconds per part.

Kaizen at process 11. The process 11 is 'tilt lever assembly with column'. The cross-functional team conducts the $3 \mathrm{M}$ analysis for the process 11 . The $3 \mathrm{M}$ analysis indicated that there were numerous activities, which had the motion waste as presented in Table 6.5.

After 3M analysis, kaizens were conducted. First, total six types of small child parts are used to assemble the tilt lever assembly with column. The child part bins were away from the operator due to which operator had to move a long distance to pick these child parts. The child part bins were relocated near to the operator. This kaizen reduced the operator fatigue and saved five seconds per part. Second, the team conducted a kaizen and provided the inclined stand near the assembly area for easy pickup of spanner and less hand movement. This kaizen saved the activity time of $0.5 \mathrm{~s}$ per part. Third, cluttering of brackets and cam-lever subassemblies creates difficulties for the operator to pick the parts and operator requires extra time for the sorting. The team conducted a kaizen activity and provided a separate stand for the bracket and cam-lever subassemblies. This kaizen saved the activity time of $1.5 \mathrm{~s}$ per part. Fourth, the team conducted a kaizen activity and provided the loctite stand at the point of use. This kaizen saved the activity time of $0.5 \mathrm{~s}$ and reduced the hand movement from 260 to $210 \mathrm{~mm}$. Fifth, the team conducted a kaizen activity and placed the marker nearer to the marking point (assembly area). This kaizen further reduced 


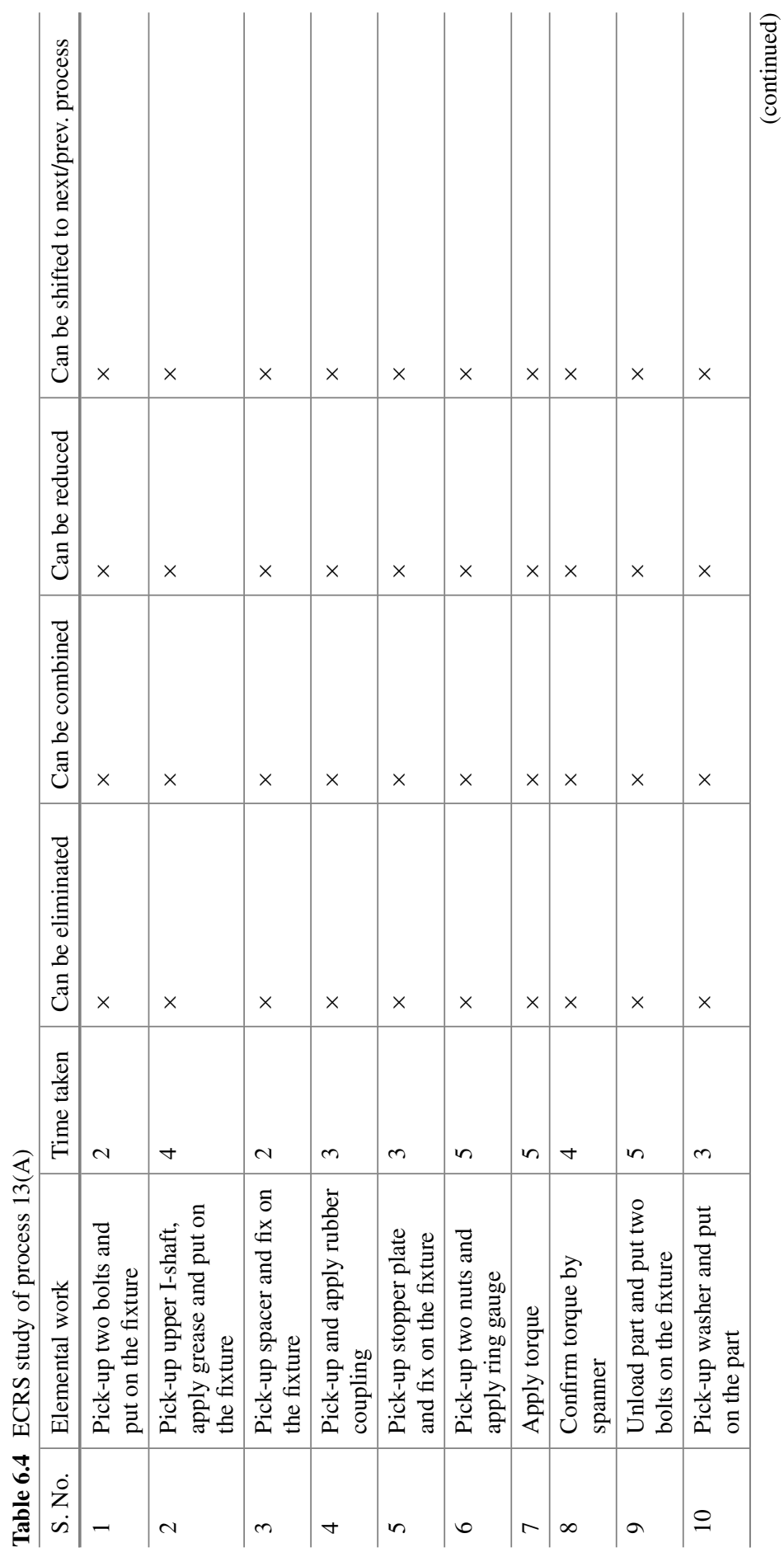




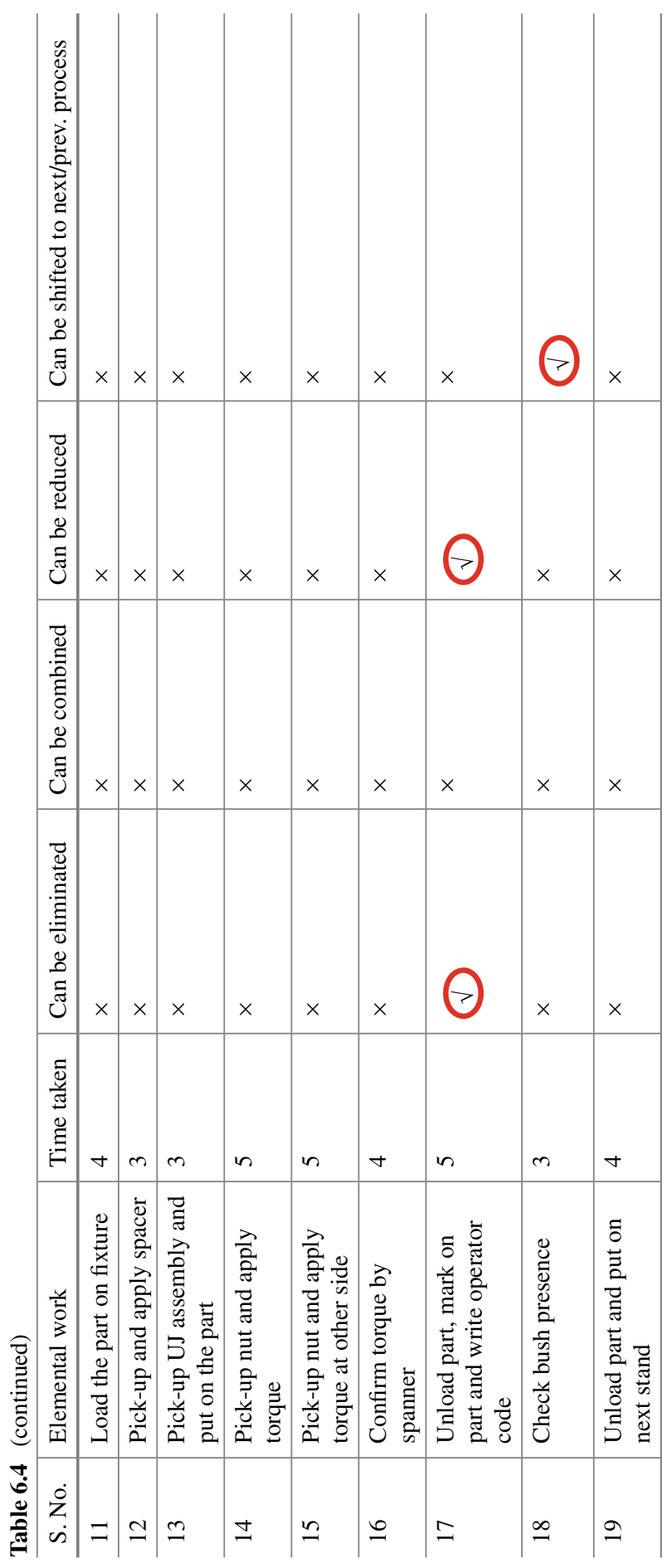


Table 6.5 $3 \mathrm{M}$ analysis of process 11

\begin{tabular}{|c|c|c|c|c|}
\hline $\begin{array}{l}\text { S. } \\
\text { No. }\end{array}$ & Process 11 & $\begin{array}{l}\text { Time } \\
(\mathrm{sec})\end{array}$ & Observation & Action plan \\
\hline 1 & $\begin{array}{l}\text { Pick-up mounting bracket and } \\
\text { put on the fixture }\end{array}$ & 4 & \multirow{5}{*}{$\begin{array}{l}\text { Pick-up time more as } \\
\text { child parts are away } \\
\text { from the operator } \\
\text { Spanner position incon- } \\
\text { venient }\end{array}$} & \multirow{5}{*}{$\begin{array}{l}\text { Put child part bin } \\
\text { nearer to the operator } \\
\text { Inclined stand provided } \\
\text { for spanner }\end{array}$} \\
\hline 2 & $\begin{array}{l}\text { Pick-up sub-assembly and fix } \\
\text { it on fixture }\end{array}$ & 7 & & \\
\hline 3 & $\begin{array}{l}\text { Pick-up washer and apply loc- } \\
\text { tite }\end{array}$ & 4 & & \\
\hline 4 & $\begin{array}{l}\text { Pick-up nylon nut, apply } \\
\text { torque by spanner and release }\end{array}$ & 9 & & \\
\hline 5 & $\begin{array}{l}\text { Pick-up cam B and fix it on } \\
\text { part }\end{array}$ & 4 & & \\
\hline 6 & Pick-up lever cam assembly & & $\begin{array}{l}\text { No designated place for } \\
\text { mounting bracket \& } \\
\text { lever }\end{array}$ & $\begin{array}{l}\text { Provide stand for lever } \\
\text { cam assembly }\end{array}$ \\
\hline 7 & $\begin{array}{l}\text { Pick-up plain washer, needle } \\
\text { bearing and fix on part }\end{array}$ & 9 & \multirow{3}{*}{$\begin{array}{l}\text { Loctite location is away } \\
\text { from the assembly point }\end{array}$} & \multirow{3}{*}{$\begin{array}{l}\text { Place the loctite near to } \\
\text { the assembly point }\end{array}$} \\
\hline 8 & Apply loctite and pick-up nut & & & \\
\hline 9 & $\begin{array}{l}\text { Apply torque and check lever } \\
\text { movement }\end{array}$ & 7 & & \\
\hline 10 & Check rotational play & 6 & \multirow{5}{*}{$\begin{array}{l}\text { Marker pick-up is dis- } \\
\text { tance long }\end{array}$} & \multirow{5}{*}{$\begin{array}{l}\text { Re-locate the marker } \\
\text { near to marking point }\end{array}$} \\
\hline 11 & Check lever force & 7 & & \\
\hline 12 & $\begin{array}{l}\text { Pick-up marker and write } \\
\text { force value }\end{array}$ & & & \\
\hline 13 & Unlock fixture & 2 & & \\
\hline 14 & Unload part and put in the bin & 5 & & \\
\hline
\end{tabular}

the activity time by $0.5 \mathrm{~s}$ and reduced the hand movement from 370 to $280 \mathrm{~mm}$. Total $8 \mathrm{~s}$ are saved by conducting the kaizen at the process 11 . However, to avoid the waiting waste, the operator working on process 11 is given two additional activities (load the part and start cycle) of process 12. Due to these additional activities, the cycle time of process 11 is increased by four seconds.

Kaizen at Process 10. Process 10 is jacket and shaft pressing. The team decided to conduct the $3 \mathrm{M}$ analysis to critically analyse the whole activities of process 10 . The 3M analysis indicates that two activities (3 and 10 in Table 6.6) have motion waste. The team conducted a kaizen activity and reduced the number of mandrel threads by decreasing the length of the mandrel. This kaizen saved the activity time of three seconds and reduced the hand movement due to decreased number of threads from 12 to six, which also results in lesser operator fatigue. 
Table 6.6 $3 \mathrm{M}$ analysis of process 10

\begin{tabular}{|c|c|c|c|c|}
\hline S. No. & Activity & Time (sec) & Observation & Action plan \\
\hline 1 & $\begin{array}{l}\text { Pick-up part from oil } \\
\text { box with circlip } \\
\text { assembly }\end{array}$ & 3 & & \\
\hline 2 & $\begin{array}{l}\text { Insert in outer jacket } \\
\text { assembly. }\end{array}$ & 3 & & \\
\hline 3 & $\begin{array}{l}\text { Pick-up mandrel and } \\
\text { assemble in part }\end{array}$ & & $\begin{array}{l}\text { Mandrel assembly } \\
\text { time is high due to } 12 \\
\text { no of threads }\end{array}$ & $\begin{array}{l}\text { Reduce no of threads } \\
\text { on mandrel }\end{array}$ \\
\hline 4 & $\begin{array}{l}\text { Load part in fixture } \\
\text { and clamp }\end{array}$ & 5 & & \\
\hline 5 & Start cycle & 2 & & \\
\hline 6 & $\begin{array}{l}\text { Pick-up retainer and } \\
\text { assemble in outer } \\
\text { jacket }\end{array}$ & 5 & & \\
\hline 7 & $\begin{array}{l}\text { Pick-up part, fit } \\
\text { circlip and mark on it }\end{array}$ & 8 & & \\
\hline 8 & Put part in oil box & 4 & & \\
\hline 9 & $\begin{array}{l}\text { Unload part, } \\
\text { de-clamp and put on } \\
\text { fixture }\end{array}$ & 6 & & \\
\hline 10 & Disassemble mandrel & & $\begin{array}{l}\text { Mandrel disassembly } \\
\text { time is high due to } 12 \\
\text { no of threads }\end{array}$ & $\begin{array}{l}\text { Reduce no of threads } \\
\text { on mandrel }\end{array}$ \\
\hline 11 & $\begin{array}{l}\text { Pick-up circlip and } \\
\text { assemble in part }\end{array}$ & 5 & & \\
\hline 12 & $\begin{array}{l}\text { Pick-up marker, mark } \\
\text { for circlip presence }\end{array}$ & 3 & & \\
\hline 13 & $\begin{array}{l}\text { Check shaft } \\
\text { movement }\end{array}$ & 7 & & \\
\hline 14 & $\begin{array}{l}\text { Write load value on } \\
\text { part and put on the } \\
\text { next fixture }\end{array}$ & 6 & & \\
\hline 15 & $\begin{array}{l}\text { Check slot dimension } \\
\text { using Go-No Go } \\
\text { Gauge }\end{array}$ & 6 & & \\
\hline 16 & $\begin{array}{l}\text { Come back to } \\
\text { pick-up part for cycle } \\
\text { next cycle }\end{array}$ & 3 & & \\
\hline
\end{tabular}




\subsection{Results and Discussion}

The case study has exhibited that considerable improvements are achieved through the implementation of continuous kaizen. The target of productivity improvement is achieved by accomplishing the continuous kaizen project. The production per labour hour (PPLH) is increased from 4.5 to 4.8 (Fig. 6.8) or the productivity is increased by $6.70 \%$.

Correspondingly, the line efficiency is also enhanced by $2.9 \%$ as shown in Fig. 6.9. The cycle time reduction is accomplished by the elimination of motion wastes. The total cycle time is reduced from 741 to $716 \mathrm{~s}$. The overall cycle time of the line is reduced from 80 to $75 \mathrm{~s}$. Further, the line balancing is also improved by decreasing the cycle time variation from 4 to $2.84 \sigma$.

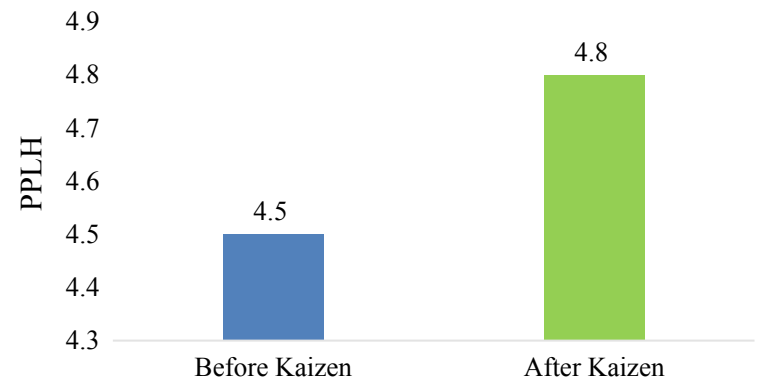

Fig. 6.8 Production per labour hour for steering column assembly

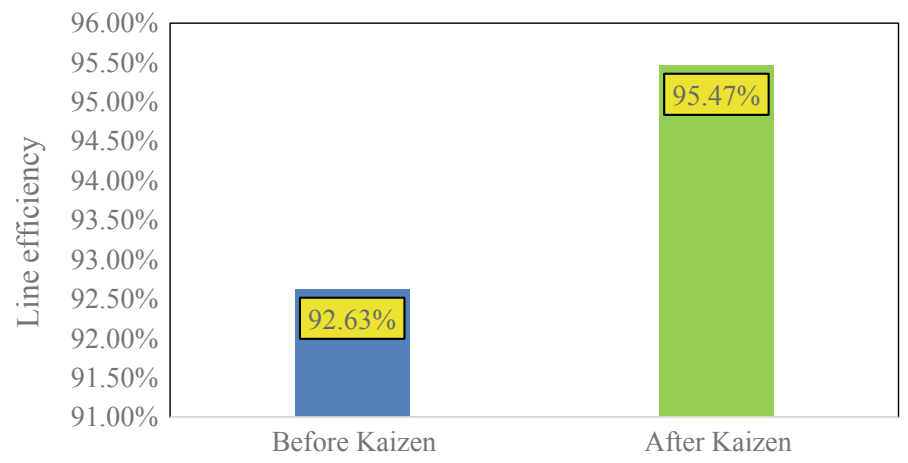

Fig. 6.9 Line efficiency of steering column assembly line 


\subsection{Conclusions}

This paper presents a case study of Indian automotive component assembly line, which shows that continuous kaizen can be used to improve leanness of an assembly line by improving the productivity, line balancing and line efficiency. The paper also proposes a new delineation of kaizen philosophy — continuous kaizen-which means continuous improvements at the global or whole value chain level instead of just 'change for better' at local or single workstation level. The various tools and techniques of the kaizen philosophy have been reviewed to provide salient points of each tool and technique. The paper also presents the methodology and tools for the proposed continuous kaizen project. The case study demonstrates the methodology required for the continuous kaizen. The continuous kaizen has improved the leanness of the assembly line by reducing or eliminating the motion waste to improve the productivity, line balancing and line efficiency. The total cycle time is reduced from 741 to $716 \mathrm{~s}$. The overall cycle time of the line is reduced from 80 to $75 \mathrm{~s}$. The continuous kaizen increased the production from 45 products per hour to 48 products per hours. The line efficiency is enhanced by $2.9 \%$. The line balancing is also improved by decreasing the cycle time variation (standard deviation) from 4 to $2.84 \sigma$. The continuous kaizen proves to be a versatile assembly line improvement approach facilitating the reduction of lean wastes.

\section{References}

Alukal G, Manos A (2006) Lean Kaizen: a simplified approach to process improvements. ASQ Quality Press, Milwaukee

Alvarado-Ramírez KM, Pumisacho-Álvaro VH, Miguel-Davila JÁ, Suárez Barraza MF (2018) Kaizen, a continuous improvement practice in organizations: a comparative study in companies from Mexico and Ecuador. TQM J 30(4):255-268

Aoki K (2008) Transferring Japanese kaizen activities to overseas plants in China. Int J Oper Prod Manag 28(6):518-539. https://doi.org/10.1108/01443570810875340

Bessant JR (2003) High-involvement innovation: building and sustaining competitive advantage through continuous change. Wiley

Bhuiyan N, Baghel A (2005) An overview of continuous improvement: from the past to the present. Manag Decis 43(5):761-771. https://doi.org/10.1108/00251740510597761

Chung CH (2018) The Kaizen wheel—an integrated philosophical foundation for total continuous improvement. TQM J 30(4):409-424. https://doi.org/10.1108/TQM-03-2018-0029

Farris JA, Van Aken EM, Doolen TL, Worley J (2008) Learning from less successful Kaizen events: a case study. Eng Manag J 20(3):10-20. https://doi.org/10.1080/10429247.2008.11431772

Imai M (1986) Kaizen - the key to Japan's competitive success. Random House, New York, NY

Marin-Garcia J, Garcia-Sabater J, Bonavia T (2009) The impact of Kaizen events on improving the performance of automotive components' first-tier suppliers. Int J Automot Technol Manag 9(4):362-376. https://doi.org/10.1504/IJATM.2009.028524

Marin-Garcia JA, Juarez-Tarraga A, Santandreu-Mascarell C (2018) Kaizen philosophy: the keys of the permanent suggestion systems analyzed from the workers' perspective. TQM J 30(4):296320. https://doi.org/10.1108/TQM-12-2017-0176 
Oropesa M, García J, Maldonado A, Martínez V (2016) The impact of managerial commitment and Kaizen benefits on companies. J Manuf Technol Manag 27(5):692-712. https://doi.org/10.1108/ JMTM-02-2016-0021

Ramadani V, Gerguri S (2011) Innovations: principles and strategies. Strateg Chang 20(3-4):101110. https://doi.org/10.1002/jsc. 888

Salzman RA (2002) Manufacturing system design: flexible manufacturing systems and value stream mapping. Massachusetts Institute of Technology

Suárez-Barraza MF, Lingham T (2008) Kaizen within Kaizen teams: continuous and Process improvements in a Spanish municipality. Asian J Qual 9(1):1-21. https://doi.org/10.1108/ 15982688200800001

Suárez-Barraza MF, Ramis-Pujol J (2010) Implementation of Lean-Kaizen in the human resource service process: a case study in a Mexican public service organization. J Manuf Technol Manag 21(3):388-410. https://doi.org/10.1108/17410381011024359

Suárez-Barraza MF, Ramis-Pujol J, Kerbache L (2011) Thoughts on Kaizen and its evolution. Three different perspectives and guiding principles. Int J Lean Six Sigma 1(2):107-129. https://doi.org/ $10.1108 / 20401461111189407$

Vonk J (2005) Process improvement in business permits through Kaizen. Spectrum 78(2):33-34

Yang Y, Lee PKC, Cheng TCE (2016) Continuous improvement competence, employee creativity, and new service development performance: a frontline employee perspective. Int J Prod Econ 171:275-288. https://doi.org/10.1016/j.ijpe.2015.08.006

Open Access This chapter is licensed under the terms of the Creative Commons Attribution 4.0 International License (http://creativecommons.org/licenses/by/4.0/), which permits use, sharing, adaptation, distribution and reproduction in any medium or format, as long as you give appropriate credit to the original author(s) and the source, provide a link to the Creative Commons license and indicate if changes were made.

The images or other third party material in this chapter are included in the chapter's Creative Commons license, unless indicated otherwise in a credit line to the material. If material is not included in the chapter's Creative Commons license and your intended use is not permitted by statutory regulation or exceeds the permitted use, you will need to obtain permission directly from the copyright holder.

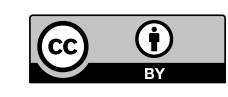

